\title{
Application of Geographic Information Systems in Groundwater Prospecting: A Case Study of Garissa County, Kenya
}

\author{
Christopher N. Muhwanga ${ }^{1}$, John P. O. Obiero' ${ }^{2}$, Faith N. Karanja ${ }^{3}$ \\ ${ }^{1}$ Department of Water Services, Ministry of Water and Irrigation, Nairobi, Kenya \\ ${ }^{2}$ Department of Environmental and Biosystems Engineering, University of Nairobi, Nairobi, Kenya \\ ${ }^{3}$ Department of Geospatial and Space Technology, University of Nairobi, Nairobi, Kenya \\ Email: *c.ndegwa@yahoo.com, pobiero2003@yahoo.com, faithkaranja@hotmail.com
}

How to cite this paper: Muhwanga, C.N., Obiero, J.P.O. and Karanja, F.N. (2018) Application of Geographic Information Systems in Groundwater Prospecting: A Case Study of Garissa County, Kenya. Journal of Geographic Information System, 10, 439-460.

https://doi.org/10.4236/jgis.2018.104023

Received: January 8, 2018

Accepted: August 20, 2018

Published: August 23, 2018

Copyright $\odot 2018$ by authors and Scientific Research Publishing Inc. This work is licensed under the Creative Co $\mathrm{m}$ mons Attribution International License (CC BY 4.0).

http://creativeco m

mons.org/licenses/by/4.0/

\section{cC) (i) Open Access}

\begin{abstract}
Groundwater prospecting in Kenya has been haphazard and expensive due to lack of information on the appropriate areas for hydrogeological exploration and drilling of boreholes. Drilling in areas without prior knowledge about their groundwater potential has been leading to the drilling of numerous dry boreholes. In this study, we explored the use of Geographic Information System as a pre-analysis tool to identify zones with groundwater potential for Garissa Country. Factors that contributed to groundwater occurrence were identified as landcover, soil type and rock formation. The groundwater potential zones were generated by analysing thematic data of the three factors and integrating the musing Weighted Index Overlay Analysis (WIOA) method. The groundwater potential zones were validated by comparing the predicted potentials with actual yields of existing boreholes drilled within those areas. Results indicate that, whereas the model correctly predicted areas with low or no groundwater potential, it performed sparingly well when predicting areas with good groundwater potential. The study conclusively identified areas where groundwater prospecting should not be attempted and other alternative methods of surface water provision should be explored.
\end{abstract}

\section{Keywords}

Groundwater, Geographic Information Systems, Weighted Index Overlay

\section{Introduction}

Kenya is classified as a water scarce country, characterized by high spatial and temporal variability in rainfall leading to extreme droughts and floods. Kenya's 
renewable fresh water supply is estimated at $647 \mathrm{~m}^{3}$ per capita, almost half the United Nations' recommended bench mark of $1000 \mathrm{~m}^{3}$ per capita. This compares dismally with its neighbours namely Uganda with $2940 \mathrm{~m}^{3}$ and Tanzania with $2696 \mathrm{~m}^{3}$ per capita respectively [1]. Kenya's fresh water supply is reducing due to declining rainfall, increase in population, and degradation of existing water catchment/conservation forest cover, and is projected to drop to $245 \mathrm{~m}^{3}$ per capita by the year 2025 [1]. Among the economically underdeveloped areas of the country, northern Kenya is the most vulnerable since water, arable land and pasture are scarce resources [2]. Famine and drought are common in this region and coupled with underdeveloped water supply facilities, water sources are a major cause of conflict between local communities [2] [3].

Northern Eastern Kenya covers the largest part of the country but has the greatest scarcity of water. This problem is as a result of many factors. Traditionally, water security has been achieved by harvesting surface water through construction of river flow obstruction/storage structures such as dams and water pans [4]. However Northern Kenya lacks suitable embankment materials and sites for construction of dams. Construction of dams would require transportation of suitable embankment materials from borrow sites in far regions which is an expensive exercise due to the bulky nature of these materials. High temperatures and poor vegetation cover that characterise the region lead to high evaporation and siltation rates respectively greatly reducing the lifespans and storage capacities of the water pans.

Groundwater source provides a viable alternative to surface water harvesting, and has proven useful in dry areas [5] [6]. However, groundwater resources in Kenya are underdeveloped with only 0.18 billion cubic meters extracted annually from a total estimated yield of 1.08 billion cubic meters [7]. Therefore there is need to identify and map potential groundwater harvesting zones in the Northern region as well as in other Arid and Semi-Arid Land (ASAL) areas in Kenya.

Garissa Country experiences water supply problems when surface water sources dry up during dry seasons. All the hinterland rivers are seasonal (Figure 1) and only River Tana flowing along the southern border offers perennial water source to the nearby communities and towns.

For many years, ground water harvesting has been tried in various parts of the country by the national government and non-govern mental organizations as an alternative water source. However, the exploration has been haphazard due to lack of information regarding groundwater potential areas. Overtime, drilling has relied on hydrogeological estimates and data from nearby boreholes, if any, which has led to the drilling of many dry or low yielding boreholes. Drilling of dry boreholes is a waste of time and precious resources. This negatively affects the livelihoods of the local community. Therefore there is an urgent need to utilize efficient pre-exploration methods to enhance use of all valuable resources.

In recent years the use of Geographic Information Systems (GIS) and Remote Sensing (RS) has made it easier to define the distribution of different groundwater 


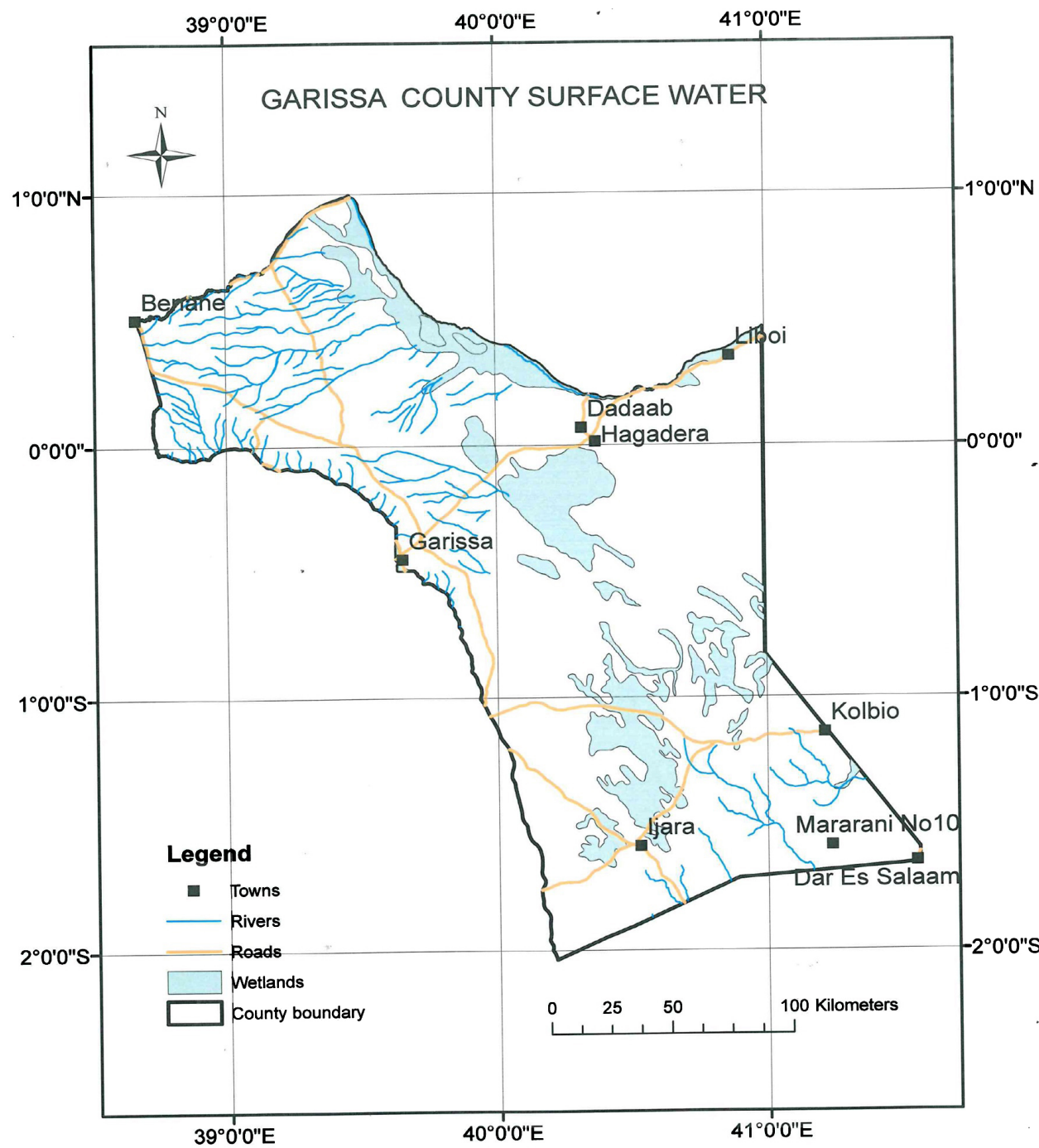

Figure 1. Distribution of surface water in Garissa Country.

prospective zones. When used in the preliminary stages of a survey, GIS and RS help in delineating potential groundwater harvesting sites based on the geo morphology, hydrogeology, vegetation, and other associated features of a region. The sites identified are then ear marked for detailed exploration work, drastically reducing the costs associated with groundwater exploration. GIS and RS techniques are used in this study to deter mine groundwater sources in Garissa Country.

The overall objective of the study was to develop a groundwater potential zones map for Garissa Country, using Weighted Index Overlay Analysis (WIOA) modelling, for selection of areas suitable for drilling of boreholes.

The specific objectives of the study were:

1) To identify factors that influence occurrence of groundwater in an area;

2) To establish suitable locations for exploration of groundwater for Garissa Country;

3) To test the validity of the generated groundwater potential map. 


\section{Methodology}

\subsection{The Study Area}

Garissa Country is comprised of the former Garissa and Ijara districts. The Country covers an area of about $34,952 \mathrm{~km}^{2}$ and has a population of more than 623,060 [8]. It borders Wajir Country in the North along Habasweni swamp and Lamu Country in the East. In the South, Tana River runs from west to east and for ms its boundary with Tana River Country. On the western side it borders Mt. Kenya game reserve and Isiolo Country. It lies in between latitudes $2^{\circ} 01^{\prime} 30^{\prime \prime S} \&$

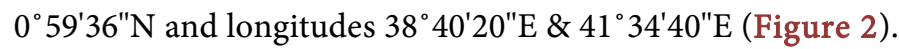

Among the counties in the Northern region, Garissa Country was chosen as a priority for this case study because of three main reasons. First, it is one of the economic gateways to the region. Second, Garissa has been characterised by insecurity for many years which curtailed water infrastructure develop ment for long. Third, Garissa Country is projected to have a significant increase in population and economic development due to the proposed Lamu Port South Sudan Ethiopia Transport (LaPSSET) corridor infrastructure development which will pass through the country (Figure 3).

\subsection{Data Collection}

\subsubsection{Existing Boreholes Data}

The Ministry of Water and Irrigation drilled boreholes nationally at a high rate

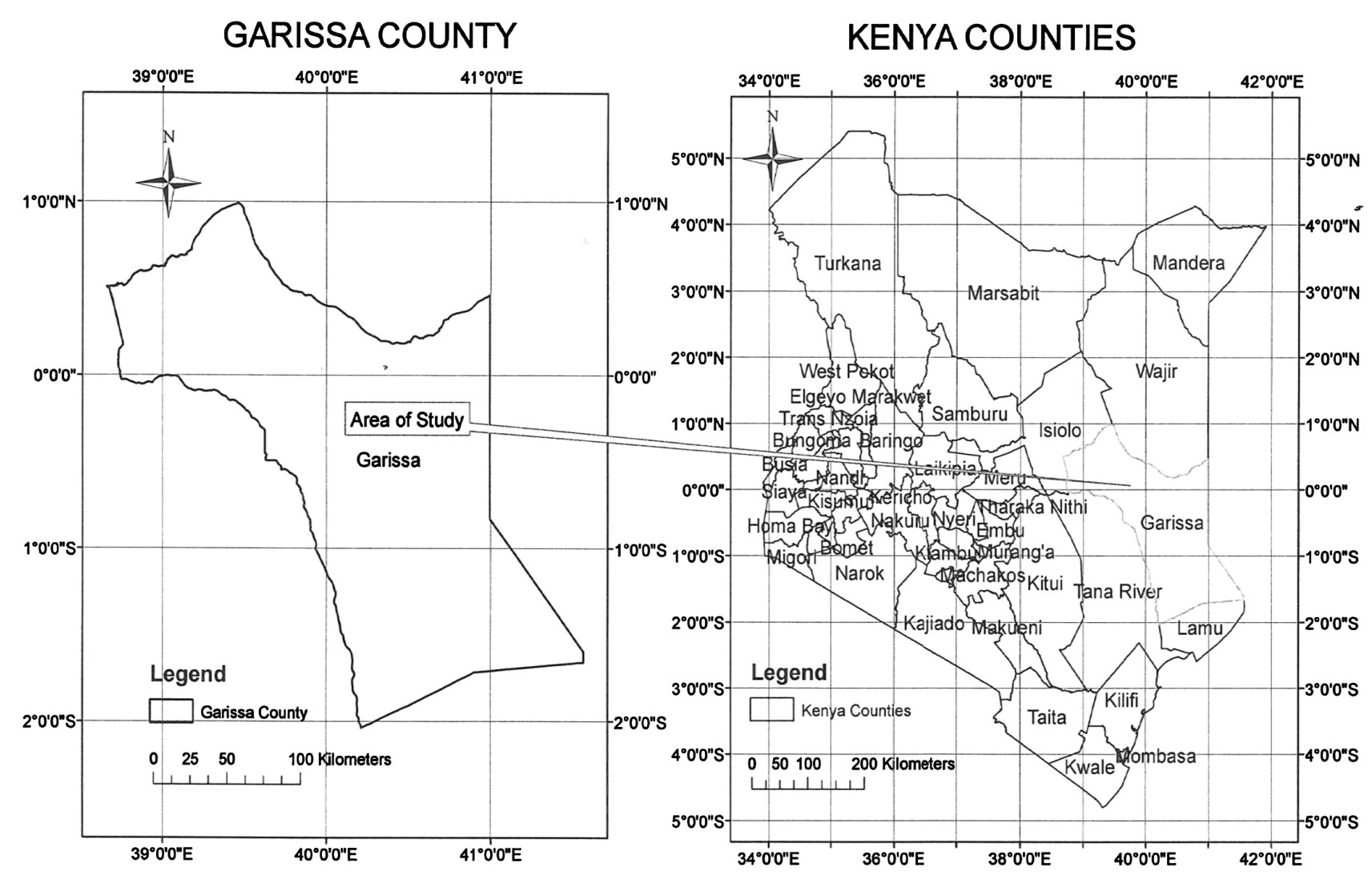

Figure 2. Location of Garissa Country. 


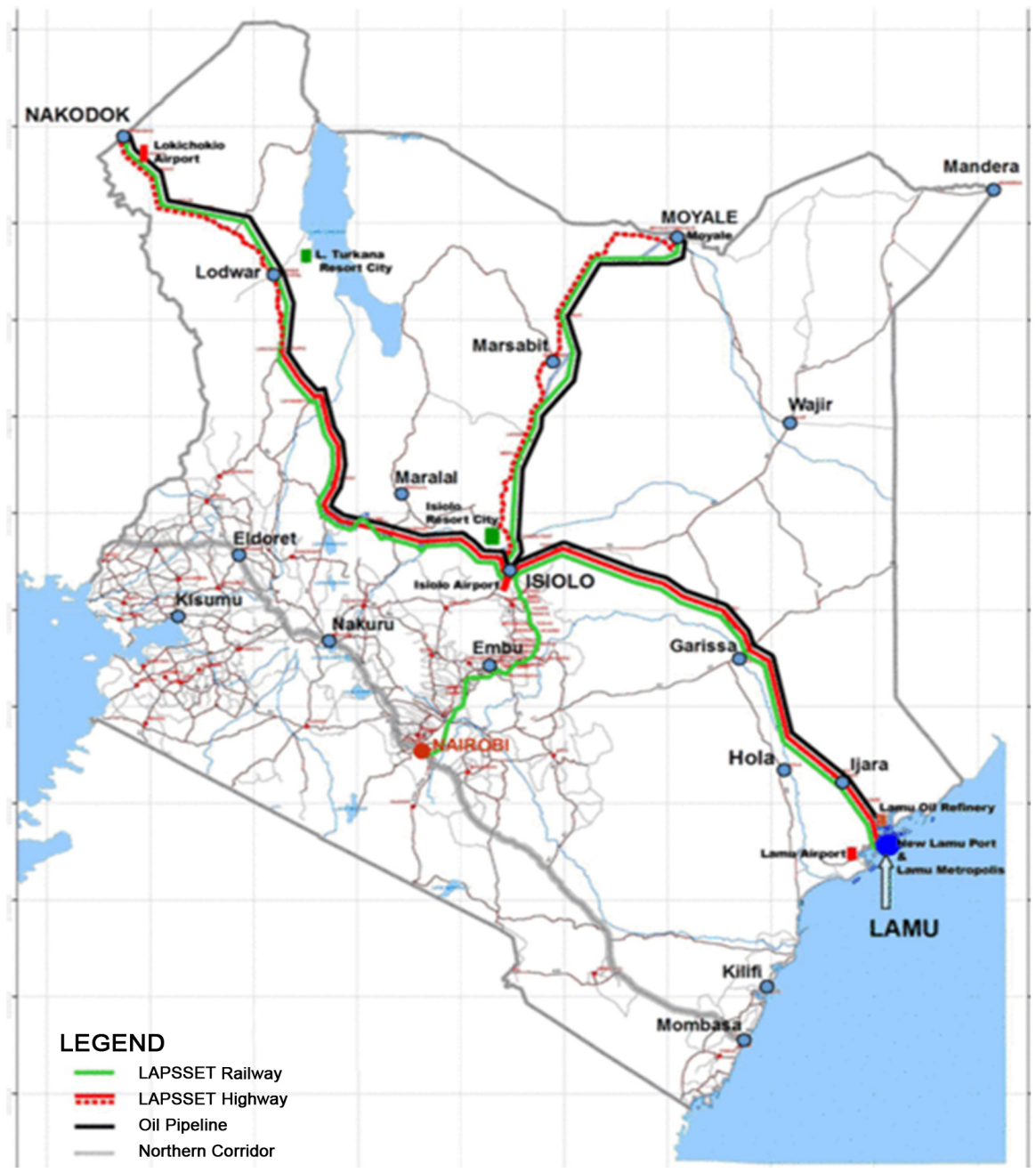

Figure 3. Map showing the scope of the Kenya LAPPSET Project within Kenya. Source: https://en.wikipedia.org/wiki/Lamu_Port_and_Lamu-Southern_Sudan-Ethiopia_Transpo rt_Corridor 2013.

from 2005 to 2010 [9]. The Northern Water Service Board (NWSB) received the greatest number of projects, therefore making the region a priority study area. The NWSB region boreholes data was extracted from boreholes drilling records obtained from National Water Conservation and Pipeline Corporation (NWCPC) for boreholes drilled during the six years development period. The boreholes raw data was screened to re move unreferenced sites to obtain complete data records. Many boreholes records were incomplete and out of 218 boreholes drilled, only 111 borehole sites were georeferenced (Table 1).

\section{Garissa Country Boreholes}

From the regional data the country data was arrived at by carrying out a comparison of the data for the seven counties. The comparison was based on the number of boreholes drilled and the number of boreholes with GPS coordinates. Garissa Country was found to have the largest number of boreholes with complete data records. The georeferenced country data was further filtered to re 
move repeated, erroneous and inconsistent records to obtain the data records that constituted the study validation data (Table 2).

Table 1. Boreholes with GPS coordinates.

\begin{tabular}{cccc}
\hline S/No. & Country & No. of boreholes & Boreholes with GPS coordinates \\
\hline 1 & Laikipia & 26 & 8 \\
2 & Isiolo & 24 & 22 \\
3 & Samburu & 19 & 8 \\
4 & Marsabit & 48 & 12 \\
5 & Mandera & 26 & 18 \\
6 & Wajir & 30 & 16 \\
& Garissa & 45 & 37 \\
& TOTAL & 218 & 111 \\
\hline
\end{tabular}

Source NWCPC borehole drilling records.

Table 2. Garissa Country study validation data.

\begin{tabular}{|c|c|c|c|c|c|}
\hline S/No. & Borehole Name & $X$ & $Y$ & Depth m & Yield $\mathrm{m} 3 / \mathrm{h}$ \\
\hline 1 & Ashadin & 39.0916 & 0.1592 & 200 & 0 \\
\hline 2 & Skanska & 39.3067 & 0.9147 & 134 & 0 \\
\hline 3 & Bulla Iftin & 39.1125 & -0.0653 & 85 & 0 \\
\hline 4 & Dujis & 39.4114 & 0.2483 & 220 & 0 \\
\hline 5 & Gurufa & 39.4658 & 0.8011 & 220 & 7 \\
\hline 6 & Abdi Samet I & 39.6558 & -0.0055 & 204 & 3 \\
\hline 7 & Katama II & 39.6558 & -0.0055 & 198 & 18 \\
\hline 8 & Dadaab II & 40.0092 & 0.1878 & 135 & 3 \\
\hline 9 & Majengo III & 40.1189 & -1.6755 & 53 & 15 \\
\hline 10 & Sareto II & 40.1356 & -0.0244 & 156 & 14 \\
\hline 11 & Kotile & 40.1461 & -1.9514 & 50 & 10 \\
\hline 12 & Sitie & 40.1708 & -0.3425 & 82 & 0 \\
\hline 13 & El-Humon & 40.2075 & 0.0828 & 170 & 8 \\
\hline 14 & Lebisigaley II & 40.285 & 0.1672 & 178 & 20 \\
\hline 15 & Mathagasi & 40.4261 & 0.1586 & 204 & 17 \\
\hline 16 & Shimbre & 40.5525 & -0.3417 & 177 & 2 \\
\hline 17 & Sangailucwp & 40.745 & -1.4188 & 170 & 0 \\
\hline 18 & Damanjare & 40.7883 & 0.1039 & 180 & 10 \\
\hline 19 & Hagarbul II & 40.8375 & -0.2494 & 210 & 0 \\
\hline 20 & Lago & 40.865 & 0.2042 & 227 & 15 \\
\hline 21 & Hulugho & 41.0283 & -1.2083 & 200 & 0 \\
\hline
\end{tabular}




\subsubsection{Groundwater Factors Data}

For this study the factors that were found to play a substantial role in influencing the occurrence of ground water in Garissa Country were landcover (vegetation), soils and lithology (rock formation). Rainfall, slope (topography) and drainage though important, were found not to play a significant role since their spatial layers are linear as compared to the others which are polygons. The groundwater factors data was obtained from ILRI website [4].

\section{Landcover Data}

Landcover (vegetation) data for the study area was acquired from the Japan International Co-Operation Agency National Water Master Plan landcover data. This data is available on the International Livestock Research Institute (ILRI) GIS portal (http://www.ilri.org/gis). The data was classified into five categories; Woodland, Dense bushes, Sparse bushes, Grassland, and Swamps (Figure 4).

\section{Soils Data}

Data on the soils type in the study area was downloaded from the International Livestock Research Institute (ILRI) GIS portal (http://www.ilri.org/gis). The data was initially generated from a study done by the Kenya Soil Survey (KSS) in 1982, and thereafter revised in 1997. The soil data was classified into 4 types; Clay, Very Clay, Loamy and Sandy Soils (Figure 5).

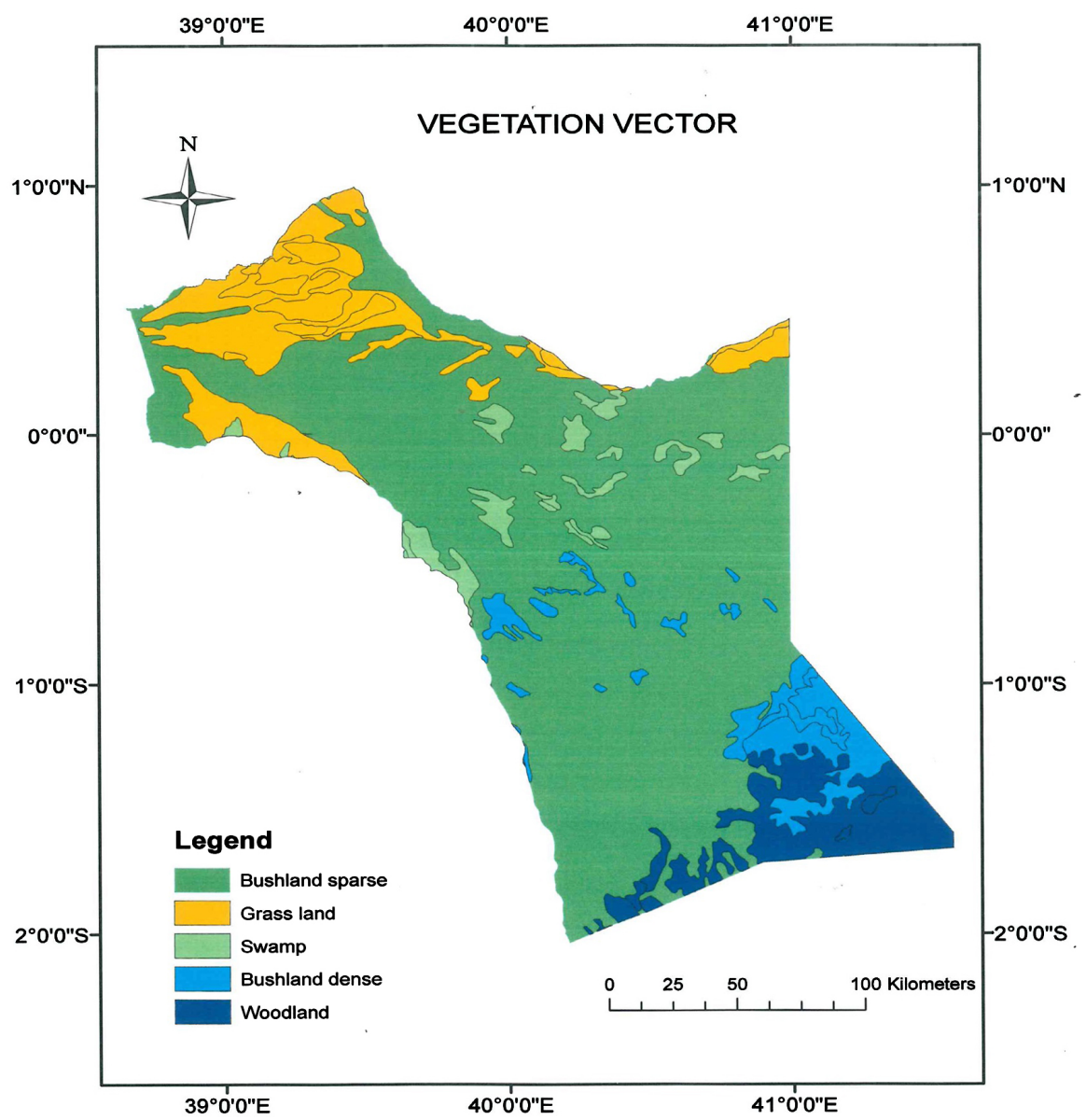

Figure 4. Landcover types in Garissa Country. 


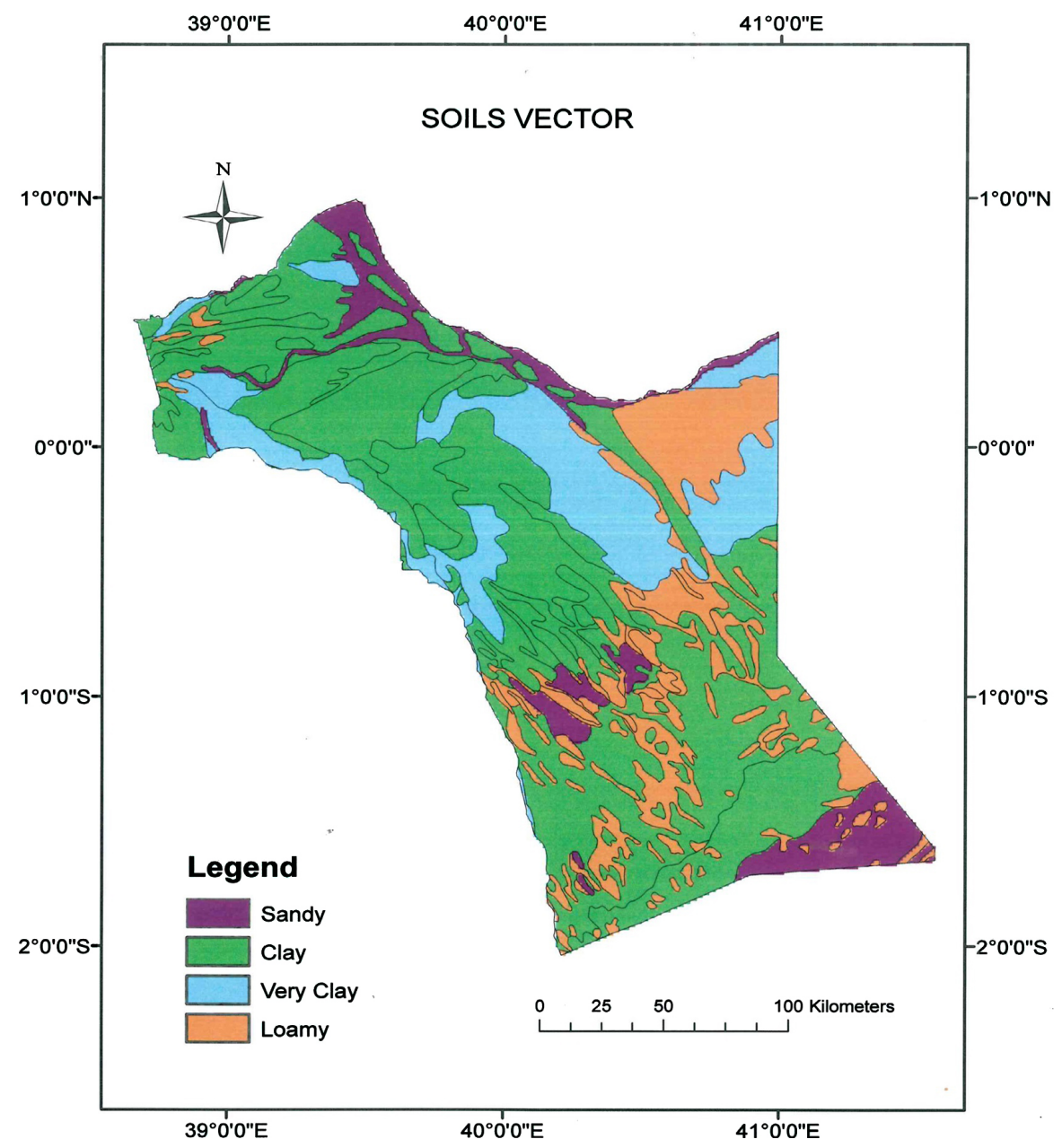

Figure 5. Soils Textural classes in Garissa Country.

\section{Lithology Data}

Data on the rock structure found beneath the surface of the study area was downloaded from the ILRI GIS portal (http://www.ilri.org/gis). The data was initially generated from a study done by the Kenya Soil Survey (KSS) in 1982. The data was classified into the following groups: Igneous, Metamorphic, Sedimentary and Unconsolidated rocks (Figure 6).

\subsection{Data Analysis}

\subsubsection{Existing Boreholes}

The data in Table 1 was used to generate a map layer showing the locations and yields of existing boreholes (Figure 7).

\subsubsection{Groundwater Factors}

\section{Conversion to Raster}

To make the Factors layers integration possible the factors data was converted from vector for mat to raster for mat using ArcGIS10.1 Arc Toolbox (conversion tools-to raster and feature to raster). The thematic factors raster layers are shown in Figure 8, Figure 9 and Figure 10. 


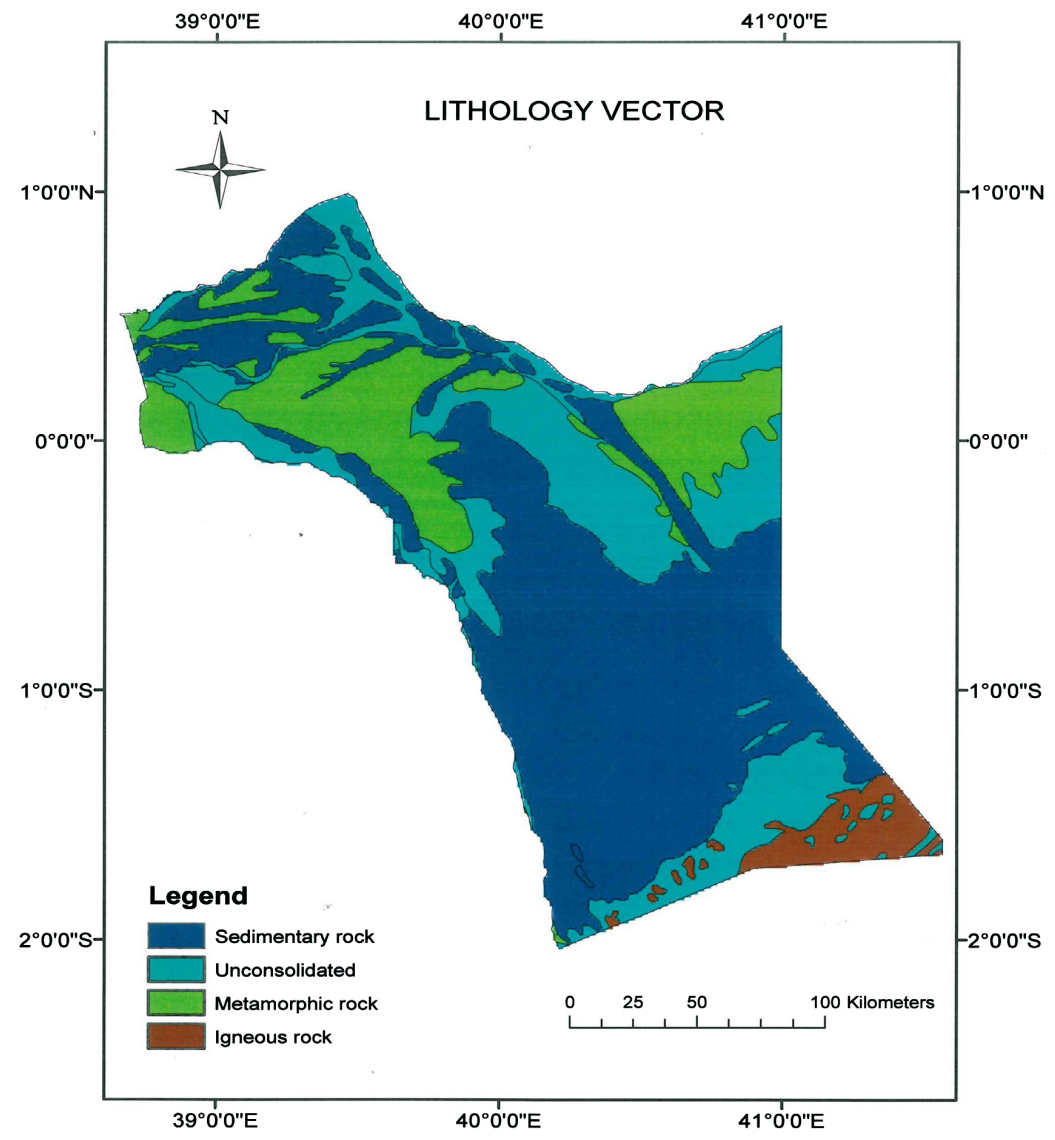

Figure 6. Underlying rock formation in Garissa Country.

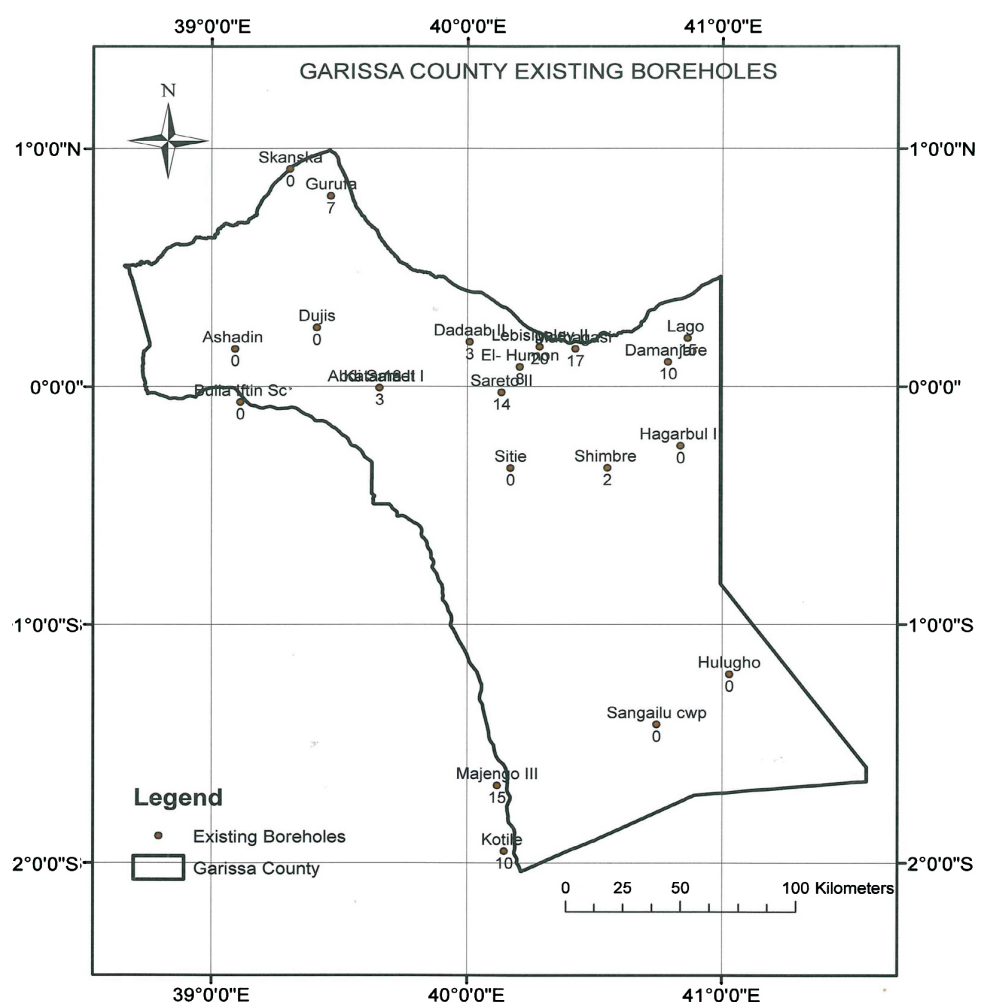

Figure 7. Map showing location of existing boreholes and their yields. 


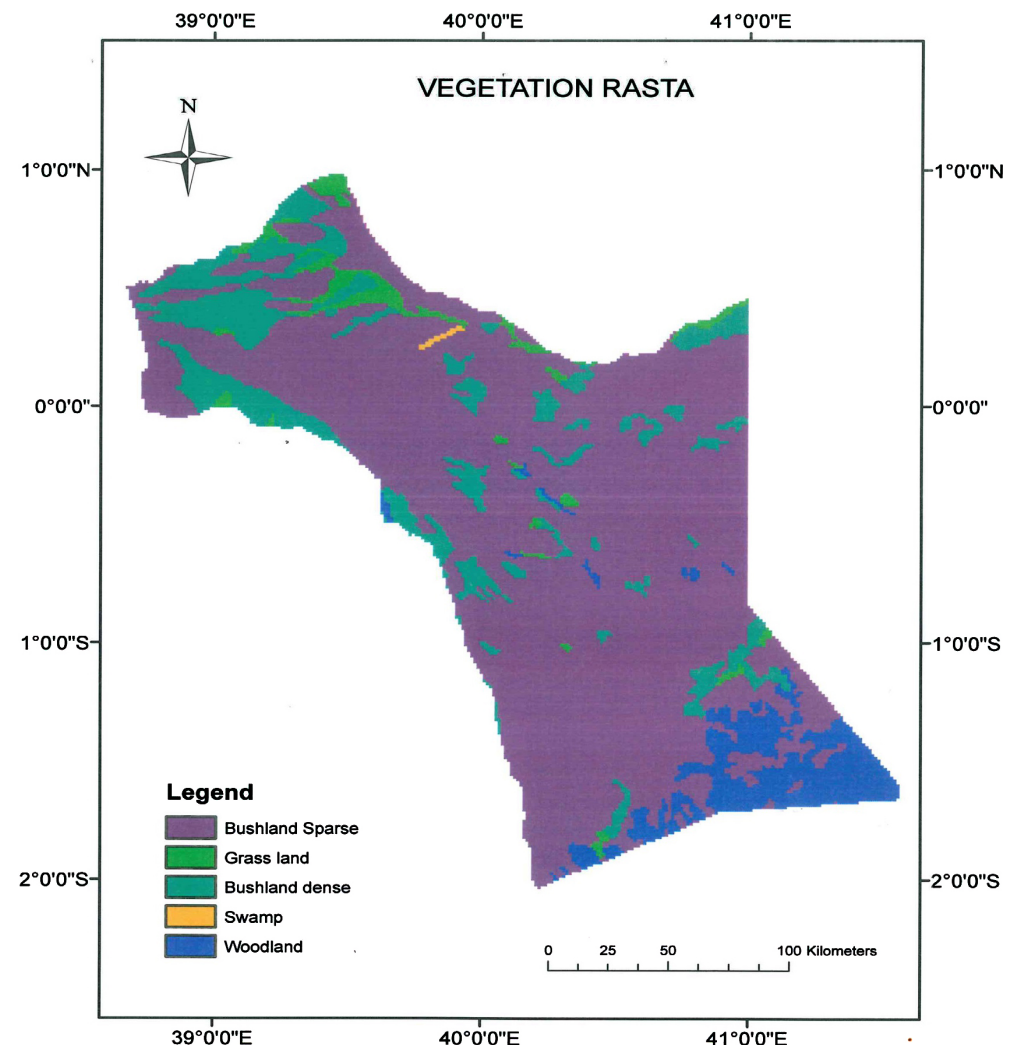

Figure 8. Garissa Country landcover raster.

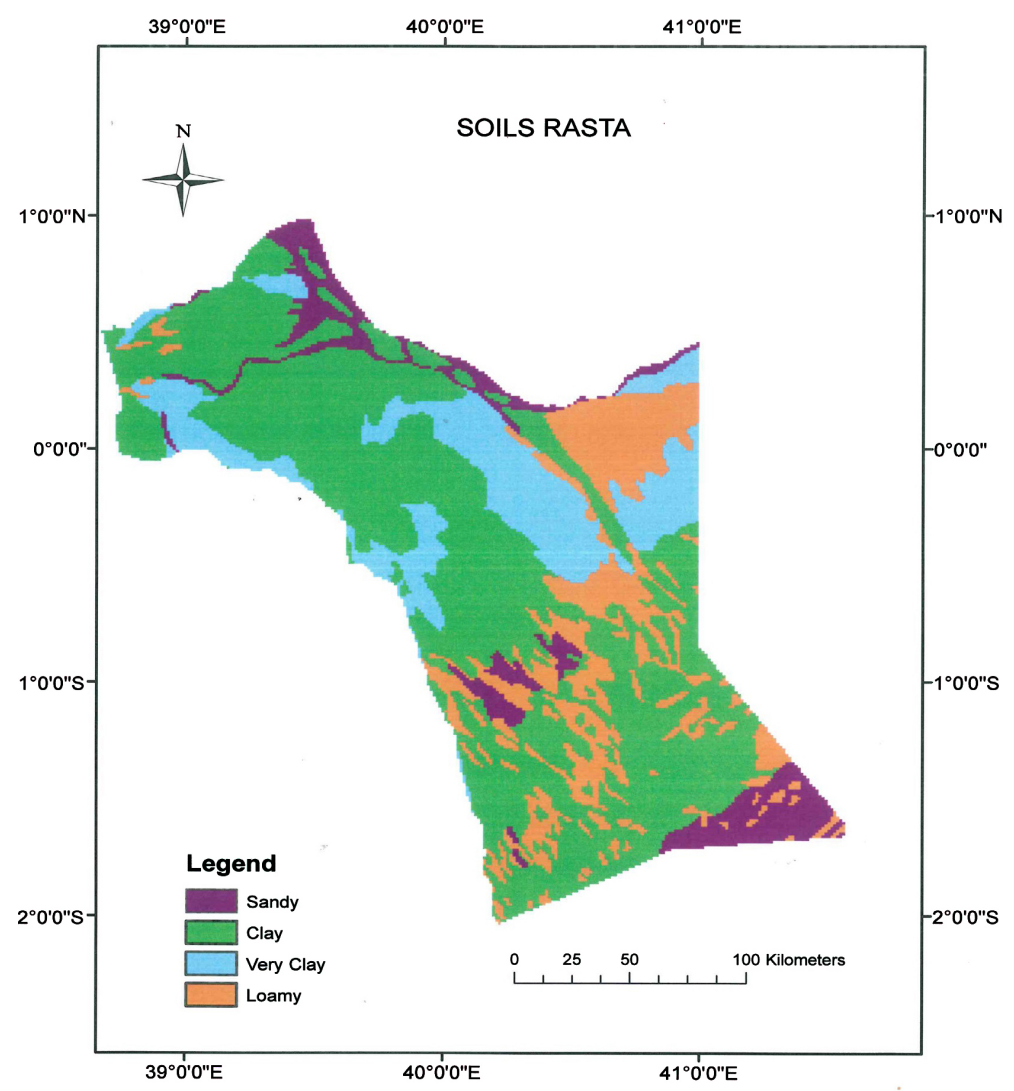

Figure 9. Garissa Country soils textural raster. 


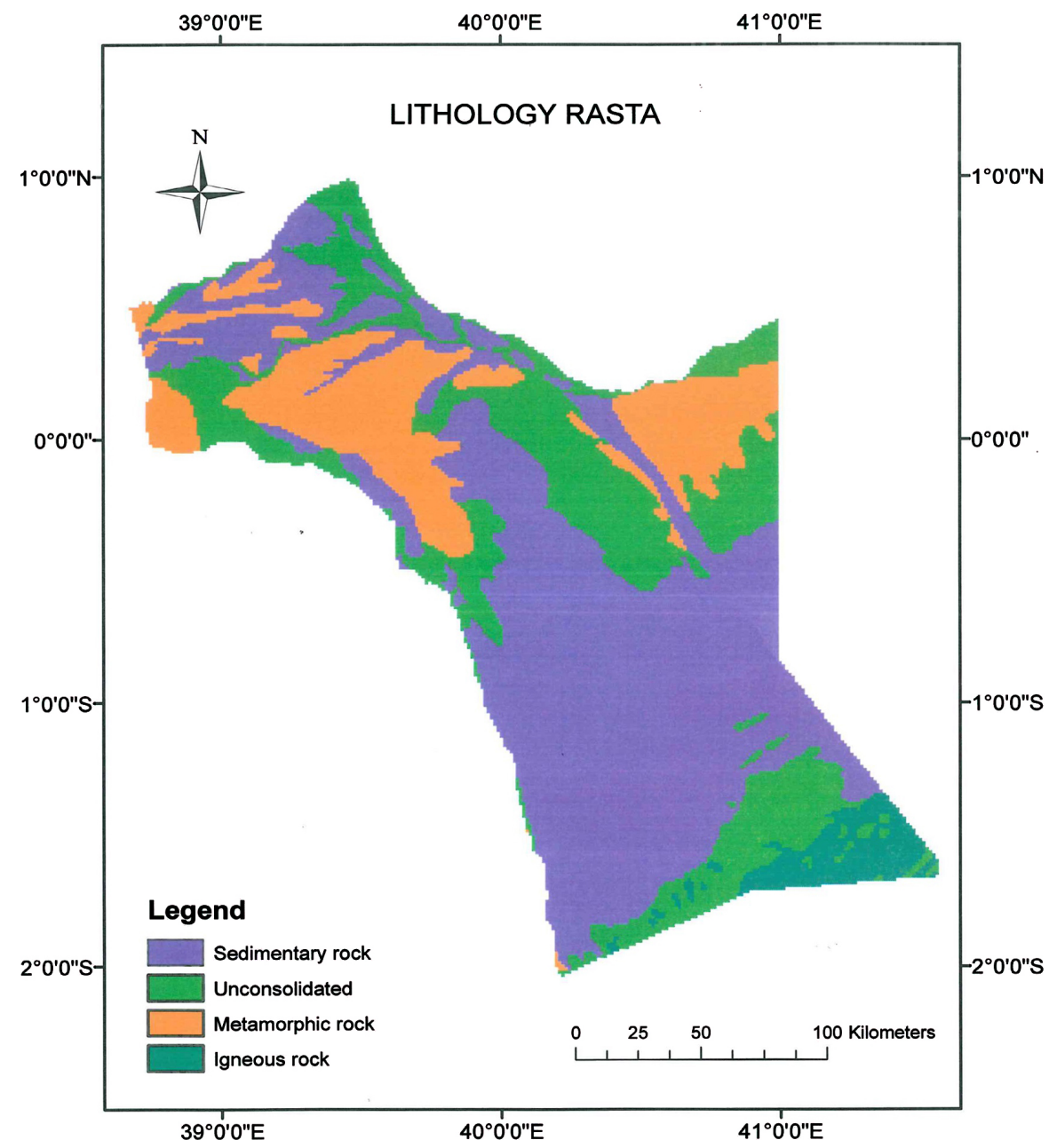

Figure 10. Garissa Country underlying rock formation raster.

\section{Reclassification to One Scale}

Integration/addition of factors layers requires them to be re-classified to a common measurement scale. A scale of 1 to 3 was chosen for this analysis. In reclassification, ranks are given to each individual parameter in each factor layer according to its relative influence on groundwater occurrence when compared to the other parameters. Using the scale of 1 to 3 each parameter in each factor layer was assigned a new value; 1-high, 2-medium, and 3-poor groundwater potential influence (Tables 3-5).

The thematic factors raster layers were then reclassified using ArcGIS10.1 Arc Toolbox (Spatial Analyst Tools-Reclass-Reclassify). The re-classed raster layers are shown in Figures 11-13.

\subsection{Weighting the Factors}

After reclassification, the three thematic (factor) layers were weighted using the Analytical Hierarchy Process (AHP) method. AHP is a logical framework that is used to deter mine the relative input of each factor towards accomplishing a certain output [10]. AHP involved pairwise comparison of the three variables (fac- 
tors) with respect to each individual variable's relative influence on groundwater potential. The comparison was done on a scale of 1 - 4 as follows; lithology is 2 times as important as soils; soil is 3 times as important as landcover and

Table 3. Vegetation re-classification.

\begin{tabular}{cccc}
\hline S/No. & Landcover & Old Value & New Value \\
\hline 1 & Woodland & 2 & 2 \\
2 & Bushland (dense) & 3 & 3 \\
3 & Bushland (sparse) & 4 & 1 \\
4 & Grassland & 5 & 2 \\
5 & Swamp & 6 & 1 \\
\hline
\end{tabular}

Table 4. Soils re-classification.

\begin{tabular}{|c|c|c|c|c|c|}
\hline S/No. & $\begin{array}{c}\text { Drainage } \\
\text { Description }\end{array}$ & $\begin{array}{c}\text { Clay } \\
\text { Description }\end{array}$ & $\begin{array}{c}\text { Texture } \\
\text { Description }\end{array}$ & $\begin{array}{c}\text { Old } \\
\text { Value }\end{array}$ & $\begin{array}{l}\text { New } \\
\text { Value }\end{array}$ \\
\hline 1 & Well & Montmorillonitic & Clayey & 1 & 2 \\
\hline 2 & Well & Kaolinitic & Clayey & 2 & 2 \\
\hline 3 & Extremely slow & Interstratified & Clayey & 3 & 3 \\
\hline 4 & Slow & Kaolinitic & Clayey & 4 & 3 \\
\hline 5 & Extremely slow & Montmorillonitic & Clayey & 5 & 3 \\
\hline 6 & Well & Montmorillonitic & Loamy & 6 & 1 \\
\hline 7 & Well & Kaolinitic & Loamy & 7 & 1 \\
\hline 8 & Slow & Montmorillonitic & Loamy & 8 & 2 \\
\hline 9 & Slow & Kaolinitic & Loamy & 9 & 2 \\
\hline 10 & Very rapid & Montmorillonitic & Sandy & 10 & 1 \\
\hline 11 & Well & Montmorillonitic & Sandy & 11 & 1 \\
\hline 12 & Slow & Montmorillonitic & Very clayey & 12 & 3 \\
\hline 13 & Extremely slow & Kaolinitic & Very clayey & 13 & 3 \\
\hline
\end{tabular}

Table 5. Lithology re-classification.

\begin{tabular}{ccccc}
\hline S/No. & Lithology & Major Class & Old Value & New Value \\
\hline 1 & Conglomerate, breccia & Sedimentary & 1 & 2 \\
7 & Sandstone, greywacke, arkose & Sedimentary & 1 & 2 \\
2 & Eolian unconsolidated & Unconsolidated & 2 & 1 \\
3 & Fluvial & Unconsolidated & 2 & 1 \\
5 & Lacustrine unconsolidated rock & Unconsolidated & 2 & 1 \\
6 & Marine unconsolidated & Unconsolidated & 2 & 3 \\
4 & Gneiss, migmatite & Metamorphic & 3 & 3 \\
8 & Ultrabasic igneous rock & Igneous rock & 4 & \\
\hline
\end{tabular}




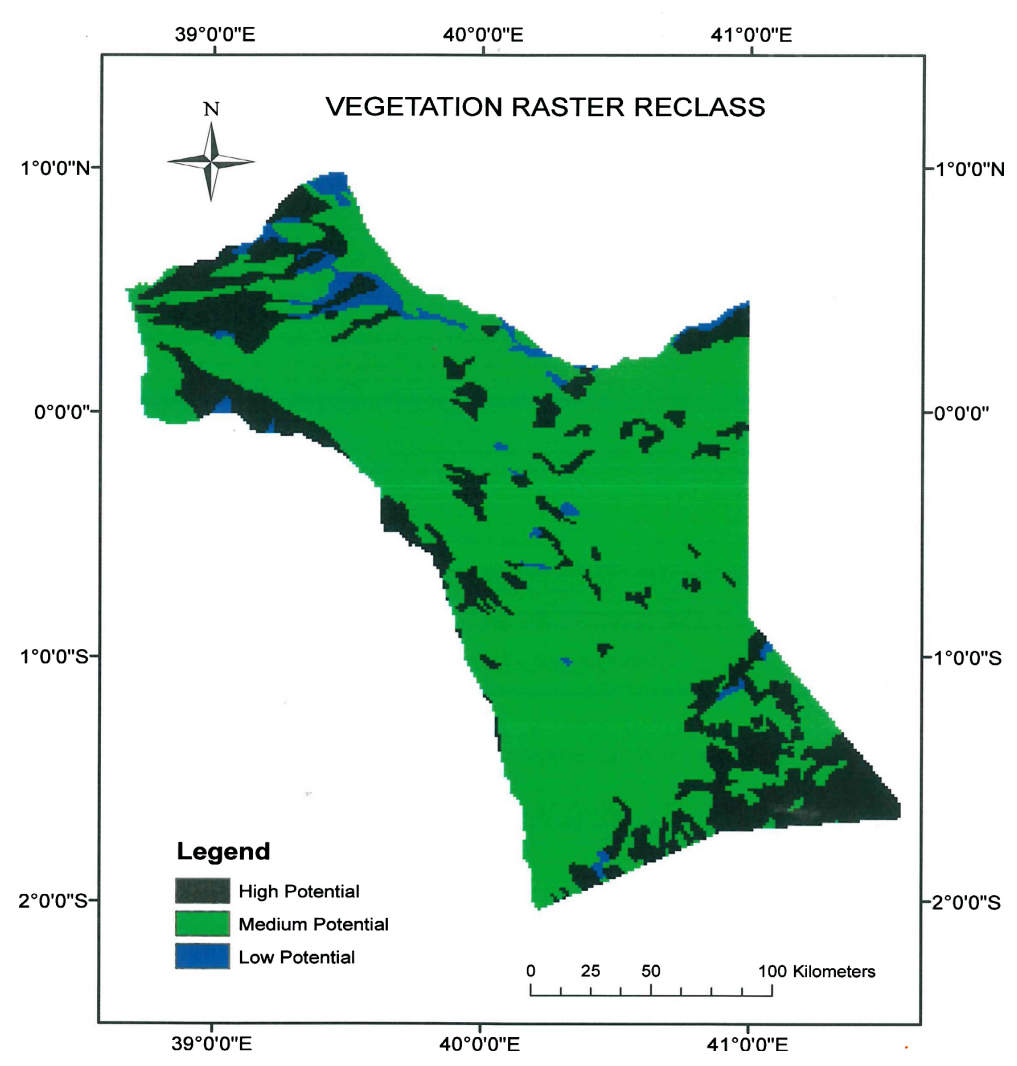

Figure 11. Garissa Country vegetation raster re-classed.

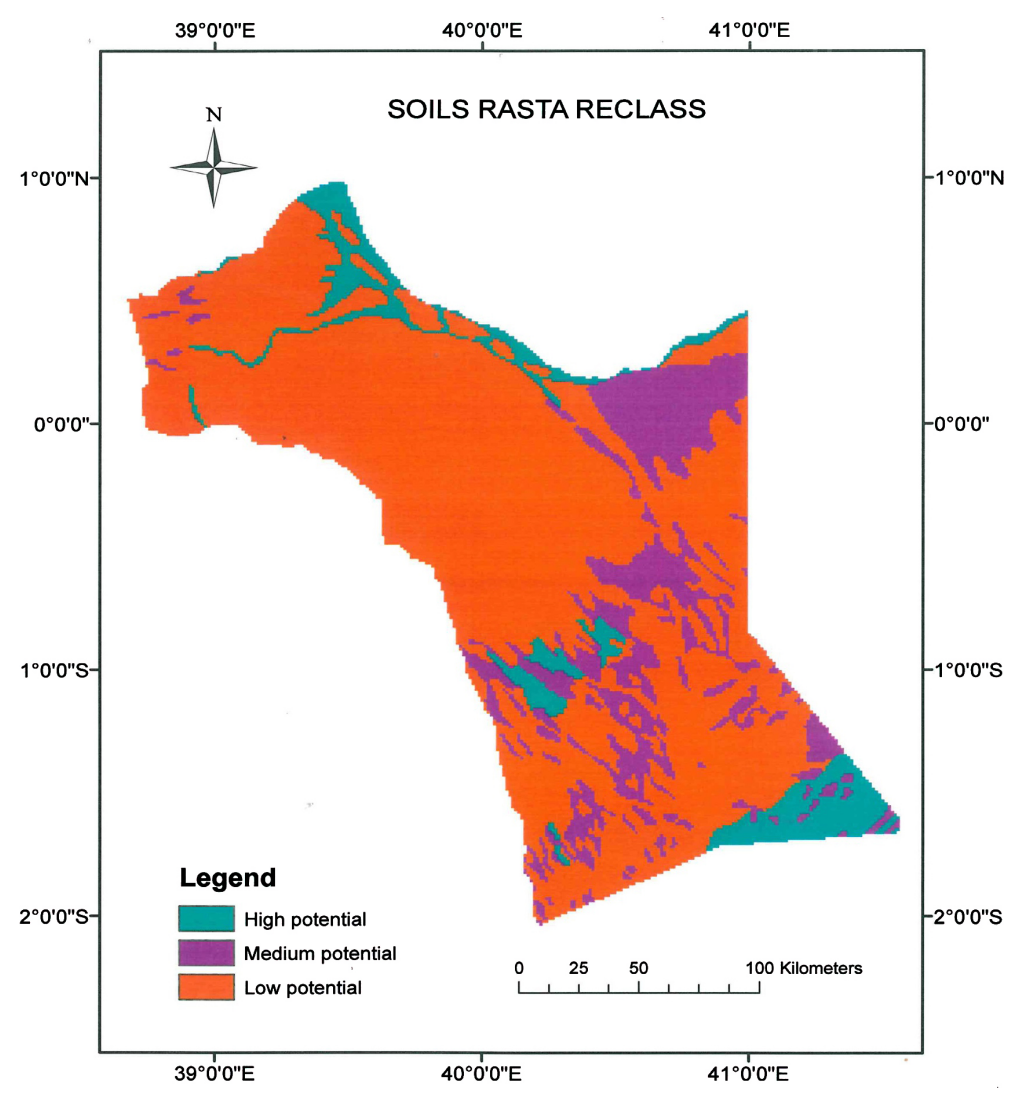

Figure 12. Garissa Country soils raster re-classed. 


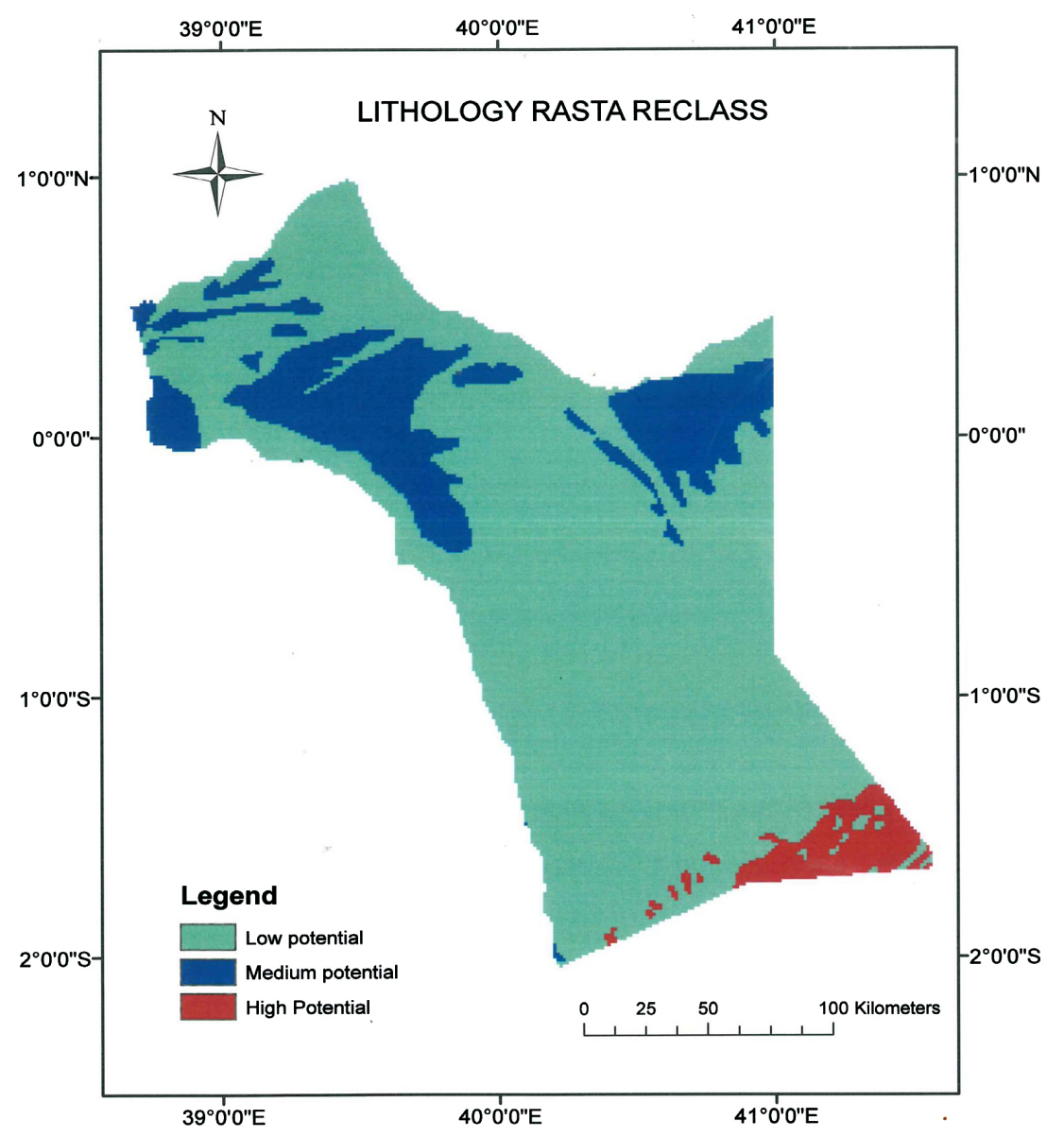

Figure 13. Garissa Country rock formation raster re-classed.

Table 6. Pairwise comparison between factors.

\begin{tabular}{cccc}
\hline & Soils & Lithology & Landcover \\
\hline Soils & $1 / 1$ & $1 / 2$ & $3 / 1$ \\
Lithology & $2 / 1$ & $1 / 1$ & $4 / 1$ \\
Landcover & $1 / 3$ & $1 / 4$ & $1 / 1$ \\
\hline
\end{tabular}

Table 7. Weights (indexes) of the factors.

\begin{tabular}{ccc}
\hline S/No. & Thematic layer & Thematic weight \\
\hline 1 & Soils & 0.32 \\
2 & Lithology & 0.56 \\
3 & Vegetation & 0.12 \\
\hline
\end{tabular}

lithology is 4 times as important as landcover. The comparison was expressed as a ratio and tabulated (Table 6).

The pairwise comparison generated a matrix that was manipulated to produce its Eigen vector. The computation stopped when the difference of Eigen vectors in two consecutive calculations was smaller than 0.001 a prescribed value. The Eigen vector gives the factors weights (Table 7). 


\section{Results and Discussion}

\subsection{Results}

\subsubsection{Integration of the Factors Layers}

After weighting, the three Factors (Vegetation, Soils and Lithology) were integrated (added) using ArcGIS10.1 Arc Toolbox (Spatial Analyst Tools-OverlayWeighted Overlay) to produce the final output (Results) which is the Groundwater potential zones. The Output produced two classes of groundwater potential zones namely; medium and low yield zones (Figure 14).

\subsubsection{Validation of the Results}

\section{Overlay with Existing Borehole Yields}

This was done by overlaying the groundwater potential zones layer (Figure 14) with the existing boreholes layer (Figure 7) and evaluating the predicted ground water potentials against the actual borehole yields. The overlay produced the validation map shown in Figure 15.

Classification of Existing Borehole Yields

After the thematic data was integrated (added) the output (groundwater

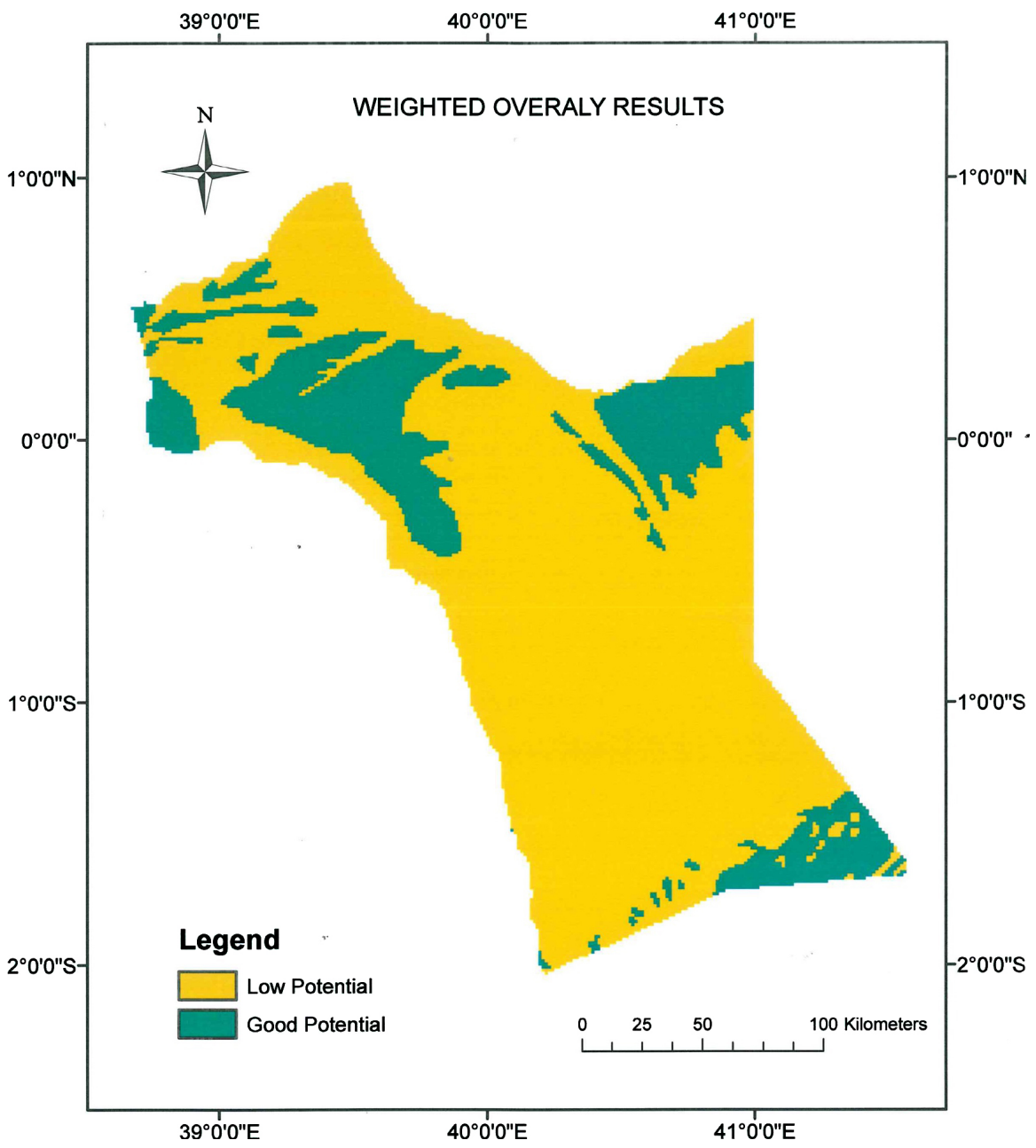

Figure 14. Garissa Country groundwater potential zones. 


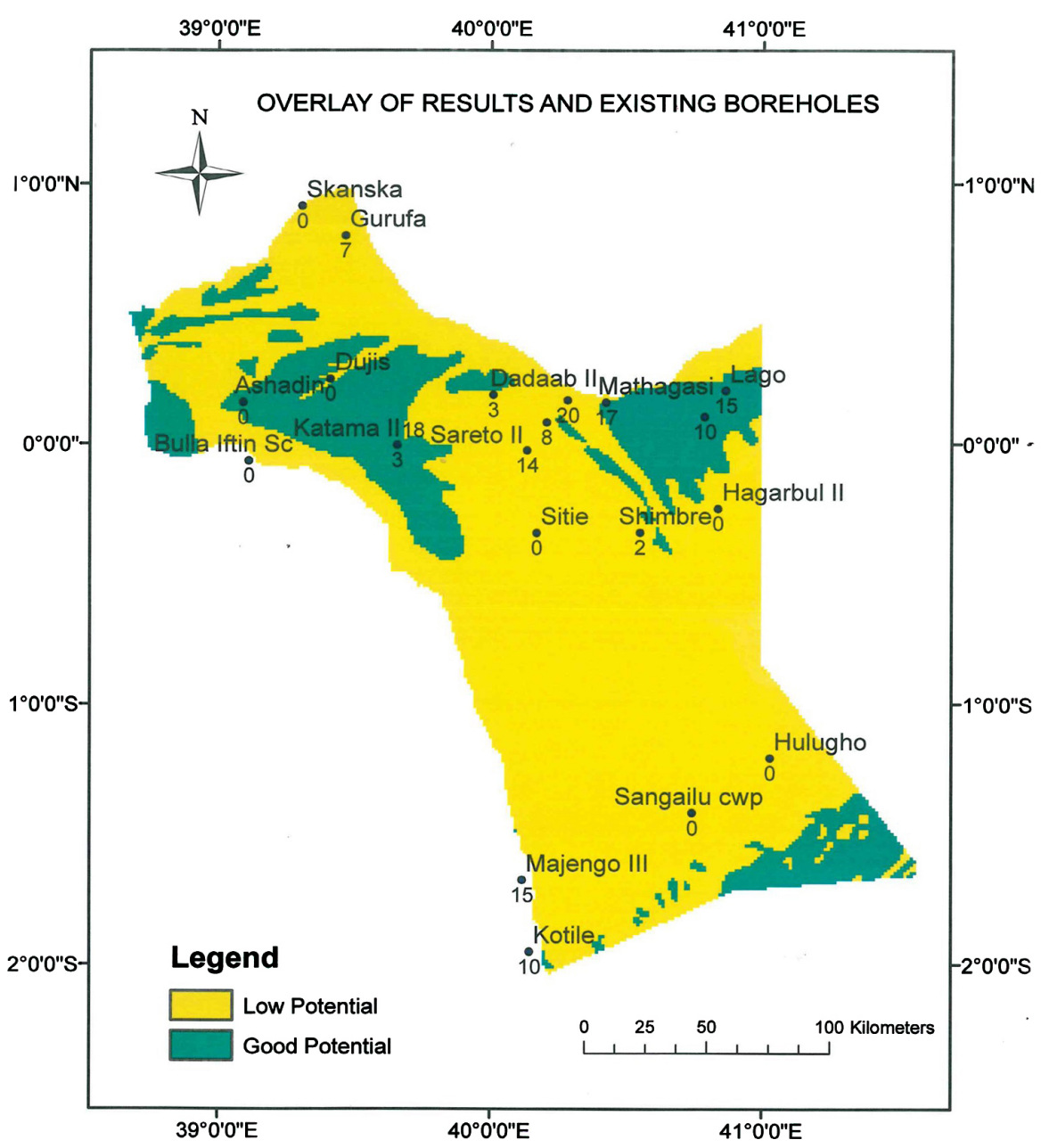

Figure 15. Overlaid groundwater potential zones with existing boreholes.

Table 8. Classified and ranked borehole yields.

\begin{tabular}{cccccc}
\hline S/No. & Yield $\mathbf{~}^{3} / \mathrm{hr}$ & Rank & Class & No. B/holes & Percentage \\
\hline 1 & $0-7$ & 2 & Low & 12 & 57.1 \\
2 & $8-20$ & 1 & Good & 9 & 42.9 \\
& Total & & & 21 & \\
\hline
\end{tabular}

potential zones map) produced two classes of groundwater potential zones namely low and medium. In this regard the existing boreholes yields were classified into two classes; 0 - 7 low and 8 - 20 good in order to enable graphical and statistical analysis (Table 8).

\section{Ranking of Borehole Yields}

To enable evaluation of the predicted groundwater potential zones against the yield values of the existing boreholes, the existing boreholes classes were ranked on a scale of 1 to 2 . Good yield boreholes were ranked 1, and low yield boreholes were ranked 2 as shown in Table 8.

\section{Ranking of Groundwater Potential Zones}

The groundwater potential zones were ranked on a scale of 1 and 2. Good po- 
tential was ranked 1 and low potential 2 as indicated in Table 9.

\section{Validation Process}

The names and yields of all the existing boreholes were tabulated. For each borehole its rank (1 or 2) Table 9 was noted and indicted as Actual Rank and its corresponding class Good or Low) noted and indicated as Actual Potential from Table 9.

From the validation map (groundwater potential zones and existing boreholes overlay) (Figure 15), the potential zone (Low or Good) in which each borehole was located was noted and indicated as predicted potential and the zone rank (1 or 2) from Table 10 noted an indicated as predicted rank.

Table 9. Ranking of groundwater potential zones.

\begin{tabular}{ccc}
\hline S/No. & Groundwater Potential Zone & Rank \\
\hline 1 & Low & 2 \\
2 & Good & 1 \\
\hline
\end{tabular}

Table 10. The model's predicted potential and boreholes actual yields.

\begin{tabular}{|c|c|c|c|c|c|c|}
\hline S/No & Name of borehole & $\begin{array}{l}\text { Yield } \\
\mathrm{M}^{3} / \mathrm{hr}\end{array}$ & $\begin{array}{c}\text { Actual } \\
\text { Rank }\end{array}$ & $\begin{array}{c}\text { Actual } \\
\text { Potential }\end{array}$ & $\begin{array}{l}\text { Predicted } \\
\text { Potential }\end{array}$ & $\begin{array}{c}\text { Predicted } \\
\text { Rank }\end{array}$ \\
\hline 1 & Ashadin & 0 & 1 & Low & Low & 1 \\
\hline 2 & Skanska & 0 & 1 & Low & Low & 1 \\
\hline 3 & Bulla Iftin & 2 & 1 & Low & Low & 1 \\
\hline 4 & Dujis & 3 & 1 & Low & Low & 1 \\
\hline 5 & Gurufa & 0 & 2 & Low & Good & 1 \\
\hline 6 & Abdi Samet I & 0 & 2 & Low & Good & 1 \\
\hline 7 & Katama II & 14 & 1 & Good & Low & 2 \\
\hline 8 & Dadaab II & 17 & 2 & Good & Good & 2 \\
\hline 9 & Majengo III & 3 & 2 & Low & Low & 2 \\
\hline 10 & Sareto II & 18 & 1 & Good & Good & 1 \\
\hline 11 & Kotile & 7 & 2 & Low & Low & 2 \\
\hline 12 & Sitie & 10 & 1 & Good & Good & 1 \\
\hline 13 & El-Humon & 0.72 & 1 & Low & Low & 1 \\
\hline 14 & Lebisigaley II & 0 & 1 & Low & Low & 1 \\
\hline 15 & Mathagasi & 0 & 1 & Low & Low & 1 \\
\hline 16 & Shimbre & 0 & 1 & Low & Low & 1 \\
\hline 17 & Sangailucwp & 8 & 1 & Good & Low & 2 \\
\hline 18 & Damanjare & 0 & 1 & Low & Low & 1 \\
\hline 19 & Hagarbul II & 20 & 1 & Good & Low & 2 \\
\hline 20 & Lago & 15 & 2 & Good & Good & 2 \\
\hline 21 & Hulugho & 0 & 1 & Low & Low & 1 \\
\hline
\end{tabular}


The comprehensive data on the model and boreholes Yields, Actual and Predicted ranks/potentials were tabulated as shown in Table 10.

\section{Graphical Comparison}

The comparison between the predicted and actual potentials was demonstrated graphically by plotting the predicted rank alongside the actual rank (Figure 16).

\section{Statistical Comparison}

It can be observed from the graphical comparison that one can't make a quick conclusion of the validation. In this regard it was necessary to exude the validation statistically. The actual and predicted potential scores were expressed inter $\mathrm{ms}$ of low and good, and analysed (Table 11).

\section{Groundwater Potential Zones Map}

From the above analysis the predicted groundwater potential zones (model results) were validly confirmed to for the Groundwater Potential Map for Garissa Country (Figure 17).

\subsection{Discussion}

\subsubsection{Groundwater Potential and Existing Data}

In this study, Weighted Index Overly Analysis and Analytical Hierarchal Process (AHP) were used to produce a Predicted Groundwater Potential Map of Garissa Country using variables known to influence groundwater in an area. A comparison of the predicted values with actual values from boreholes drilled in the area indicated that out of the 21 boreholes sampled, the model correctly predicted the potential of 16 boreholes $(76.1 \%)$. The model wrongly predicted the potential of 5 boreholes (23.8\%). Interestingly, out of the 14 sites with low

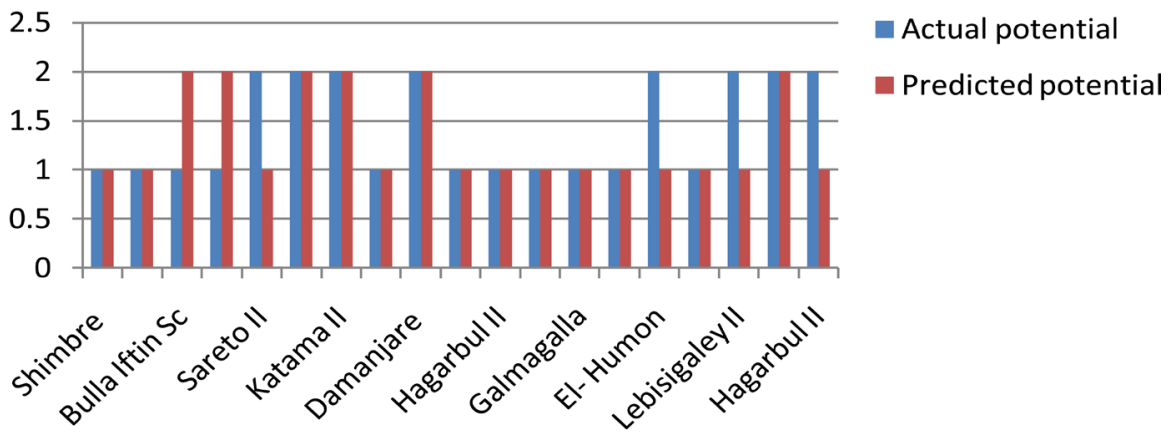

Figure 16. Predicted potential plotted against the actual potential.

Table 11. Predicted vs actual potential analysis.

\begin{tabular}{ccccccc}
\hline \multirow{2}{*}{ S/No. } & \multicolumn{2}{c}{ Yield $\mathbf{M}^{3} / \mathrm{hr}$} & \multicolumn{4}{c}{ GW Potential } \\
\cline { 2 - 7 } & Class & Score & Correct & Wrong & Total & $\%$ \\
\hline 1 & $0-7$ & Low & 12 & 2 & 14 & 85.7 \\
2 & $>8$ & Good & 4 & 3 & 7 & 57.1 \\
& Total & & 16 & 5 & 21 & 76.1 \\
\hline
\end{tabular}




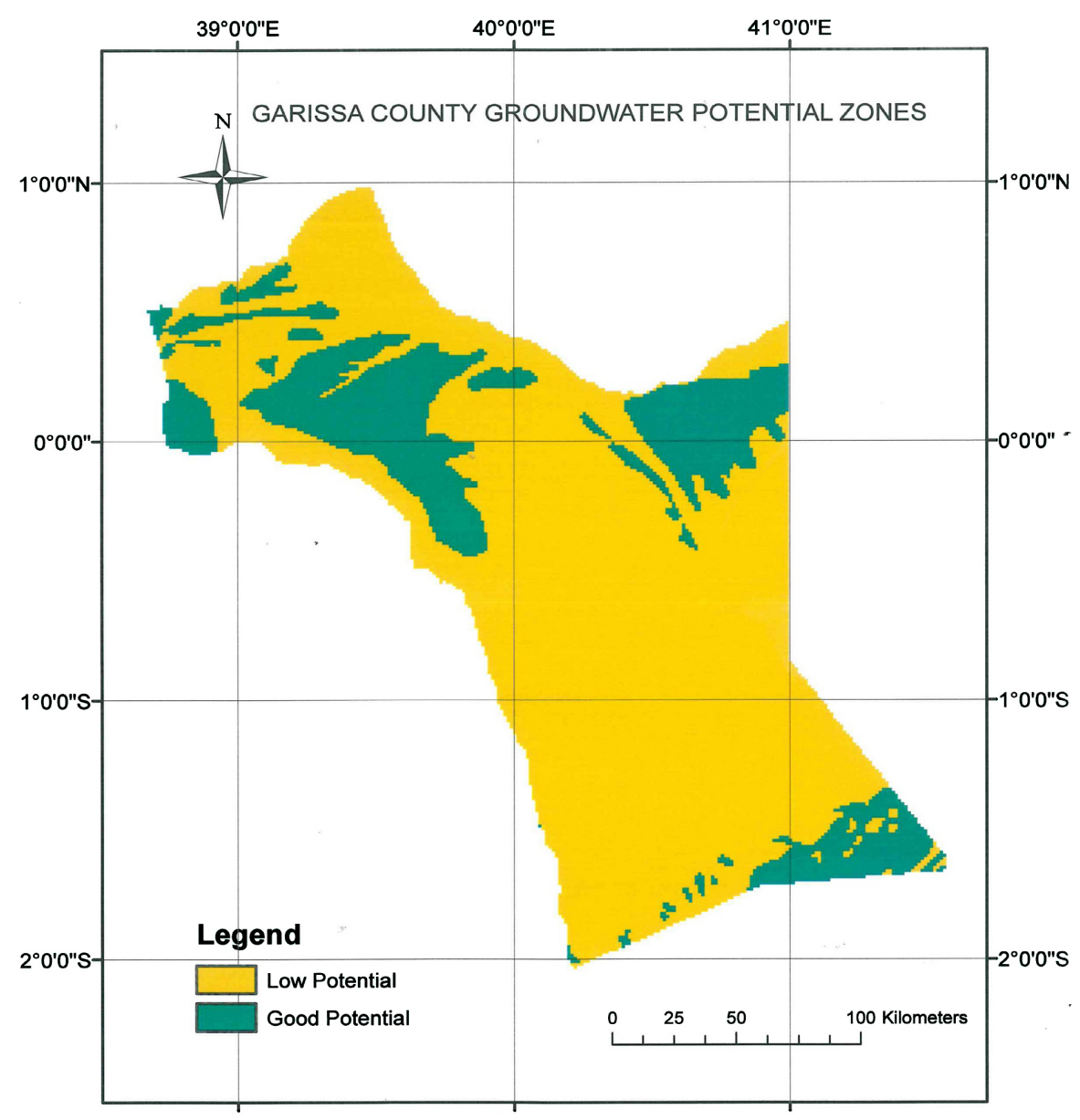

Figure 17. Groundwater potential map for Garissa Country.

Table 12. Overall borehole yields comparison.

\begin{tabular}{cccc}
\hline S/No. & Yield $\mathbf{M}^{3} / \mathbf{h r}$ & Boreholes & Percentage \\
\hline 1 & $0-1$ & 10 & 47.7 \\
2 & $2-7$ & 4 & 19.0 \\
3 & $8-14$ & 3 & 14.3 \\
4 & $15-20$ & 4 & 19.0 \\
& Total & 21 & 100 \\
\hline
\end{tabular}

potential for groundwater, the model correctly predicted 12 sites (85.7\%) and out of the 7 good sites the model correctly predicted 4 sites (57.1\%). This result indicated that the model showed good results when predicting areas with poor potential for groundwater (Table 12).

\section{Existing Data}

Existing data of drilled boreholes indicates that majority of boreholes in Garissa yielded no water (47.7\%), with only $19 \%$ of the boreholes drilled yielding high volumes of water. About $33 \%$ of the boreholes yielded low volumes (Table 12). 
Table 13. Factors relative contribution to groundwater.

\begin{tabular}{ccc}
\hline S/No. & Factor & \% Contribution \\
\hline 1 & Lithology & 56 \\
2 & Soils & 32 \\
3 & Landcover & 12 \\
\hline
\end{tabular}

\section{Groundwater Factors}

The analysis indicated that lithology of the area had the biggest influence on groundwater potential, accounting for $56 \%$ of the generated groundwater potential. Soils had the second largest influence on groundwater potential accounting for $32 \%$ of the potential and vegetation accounted for only $12 \%$ of the groundwater occurrence (Table 13).

Despite the lithology in the country showing great potential for groundwater, overall, the influence of the other factors contribute to the poor groundwater potential experienced in Garissa.

\subsubsection{Past Studies and Limitations}

Numerous studies have been carried out to map groundwater potential in many regions where consistent supply of surface water is not guaranteed. Water resources managers have taken advantage of the ability to quickly create GIS models, making GIS the "go to" tool when looking at problems dealing with water management, and in particular groundwater exploration.

Few studies corroborate the findings of their model with actual data on the ground, mainly because such data is difficult to obtain or has not been generated. Where possible it is recommended that GIS modelling results are validated with ground data.

\section{Conclusions and Recommendations}

\subsection{Conclusions}

- It is established that provided the model is used as a pre-analysis tool. The result of the model can give useful information to planners in that whereas the map generated here does not accurately indicate sites where drilling is to be done, it accurately predicts areas where the groundwater potential is poor and drilling of boreholes should be avoided.

- The model and actual borehole yields showed similar results when overlaid. About $57 \%$ of the borehole yields confirmed that the model correctly predicted the zones with good groundwater potential and $86 \%$ of boreholes confirmed zones with poor potential and an overall accuracy of $76 \%$.

- The model clearly delineates areas with poor ground water potential where drilling of boreholes will not be used as a method of water supply and other methods of water provision should be explored thus saving time and other resources. 


\subsection{Recommendations}

- Prospecting for groundwater in areas predicted to have good potential require caution since groundwater is not uniformly distributed underneath. Exploration for suitable sites will require use of other available supplementary information such as yields and depths of existing boreholes to evaluate the suitability of a site before borehole drilling work commences.

- The output can be improved by improving the quantity and quality of the study validation data by carrying out field visits to confirm the GPS coordinates and yield values of the all the 37 mapped sites. Therefore a complete mapping of all the existing boreholes will ensure the use of the model in a more conclusive pre-analysis excise.

- The user of the model need to be aware that the actual results may differ from expected results since the whole process is approximation to the end and not a definite conclusion of the outcome.

\section{Acknowledgements}

I sincerely express my heartfelt appreciation to my co-authors Dr. J. P. O. Obiero and Dr. Ing. F. N., Karanja of University of Nairobi.

My gratitude also goes to Mr. J. M. Njaaga and Mr. P. K. Muriithi, of National Water Conservation and Pipeline Co-operation, for availing boreholes data.

Finally, I thank Mr. T. Wango and Mr. T. Nganga for lending Geographic Information System and Groundwater reference materials.

\section{Conflicts of Interest}

The authors declare no conflicts of interest regarding the publication of this paper.

\section{References}

[1] MWI (2005) Kenya National Water Development Report, National Water Development Report. UN-Water/WWAP/2006/12, Boise.

[2] Dietz, T., Adano, W.R. and Witsenburg, K. (2012) Natural Resources and Conflicts: Theoretical Flaws and Empirical Evidence from Northern Kenya. Spaces of Insecurity: Human Agency in Violent Conflicts in Kenya. Vol. 45, African Studies Center, Leiden, 141-166.

[3] Haro, G.O., Doyo, G.J. and McPeak, J.G. (2005) Linkages between Community, Environ Mental, and Conflict Management: Experiences from Northern Kenya. World Development, 33, 285-299. https://doi.org/10.1016/j.worlddev.2004.07.014

[4] ILRI (2007) International Livestock Research Institute (ILRI), GIS Service. http://www.ilri.org/GIS

[5] Siebert, S., Burke, J., Faures, J.M., Frenken, K., Hoogeveen, J., Döll, P. and Port mann, F.T. (2010) Groundwater Use for Irrigation-A Global Inventory. Hydrology and Earth System Sciences, 14, 1863-1880.

https://doi.org/10.5194/hess-14-1863-2010

[6] Bhatnagar, D. and Goyal, S. (2012) Ground Water Potential Zones Mapping through Multi-Criteria Analysis: A Case Study of Sub-Watershed of Katni River Ba- 
sin. International Journal of Remote Sensing and Geoscience, 1, 22-26.

[7] Kuria, D.N., Gachari, M.K., Macharia, M.W. and Mungai, E. (2012) Mapping Groundwater Potential in Kitui District, Kenya. International Journal of water Resources and Environ mental Engineering, 4, 15-22.

[8] KNBS (2009) Population and Housing Census Results. http://www.knbs.or.ke/docs/presentation

[9] NWCPC (2010) National Water Conservation and Pipeline Corporation Service Charter.

[10] Saaty, T.L. (1991) How to Make a Decision: The Analytic Hierarchy Process. European Journal of Operations Research, 48, 9-26.

https://doi.org/10.1016/0377-2217(90)90057-I 